\title{
Health Risk Assessed by Temporal Course of Weight Gain
}

\author{
Katsumi Yoshida, Hiroshi Matsuda, Takashi Muto, \\ Haruhiko Sakurai and Haruo Kondo \\ Department of Preventive Medicine and Public Health, School of Medicine, Keio University, Tokyo
}

\section{INTRODUCTION}

Obesity is recognized as a risk factor in most chronic diseases ${ }^{1}$. Various indices are used to evaluate the degree of obesity, most of which are usually calculated based on height and body weight ${ }^{2,3)}$.

However, obesity indices calculated based on height and body weight occasionally differ with respect to the excessive accumulation of body fat ${ }^{4}$. Thus, they have limits in the assessment of health risks to the obese. In recent years, long-term weight history has been considered as an excellent index for evaluation of health risks in individual subjects ${ }^{5,6}$.

Our recent research ${ }^{7}$ has shown that subjects whose body weights have increased more than 7 kilograms since their adolescence have exacerbated medical problems associated with ischemic heart diseases.

However, how the health risks are influenced by the temporal course of weight gain remains to be elucidated. Currently, the rate of weight gain is considered to be a useful index for selecting persons at high risk when health education for obese persons is carried out.

The purpose of this study was to elucidate epidemiologically the health risks induced by the temporal course of weight gain utilizing an occupational medical database.

\section{SubJECTS AND METHODS}

Company medical records of 1,627 male employees from their dates of hiring were collected. The subjects for analysis were selected from the 1,627 employees based on the following two criteria for eligibility.

1. The subject had undergone health checkups on more than 20 occasions since being hired.

2. Weight gain since adolescence has exceeded 7 kilograms.

Four hundred and thirty-seven subjects met the above criteria. The average subject age was $46.2 \pm$ 5.1 (Mean \pm S.D.) years.

The subjects were divided into three groups according to the temporal course of their weight gain. Subjects who experienced weight gains of more than 5 kilograms per 5 years were defined as the rapid weight-gain group. The moderate weight-gain group was defined as the subjects who gained less than 5 kilograms per 5 years. The miscellaneous group was defined as the subjects who had shown temporary weight loss during the observation period.

One hundred and sixty-seven subjects $(38.2 \%)$ were assigned to the rapid weight-gain group, 212 (48.5\%) to the moderate weight-gain group, and 58 (13.3\%) were classified as the miscellaneous weight-gain group. This miscellaneous group was excluded from further analysis.

Systolic and diastolic blood pressure, total cholesterol, triglyceride, fasting blood glucose and uric acid were used as the medical test items in this analysis. The methods of measurement have been described in a previous paper ${ }^{8)}$.

The following references were adopthed as the criteria for abnormal levels of the medical test items: systolic blood pressure over $140 \mathrm{mmHg}$, diastolic blood pressure over $90 \mathrm{mmHg}$, total cholesterol over 230 $\mathrm{mg} / \mathrm{d} l$, triglyceride over $200 \mathrm{mg} / \mathrm{d} l$, fasting blood glucose over $110 \mathrm{mg} / \mathrm{d} l$ and uric acid over $7 \mathrm{mg} / \mathrm{d} l$. 


\section{PROCEDURE OF ANALYSIS}

1. Prevalence of abnormal findings based on the rate of weight gain and the current relative body weight

Current relative body weight is recognized as a factor that influences the prevalence of abnormal findings of medical test items ${ }^{9}$. Relative body weight was handled as a confounding variable in analysis of the influence induced by the temporal course of weight gain. Comparison of the prevalence of abnormal findings between the different weight-gain groups was conducted for each medical test item. Statistical comparison was conducted by Student's $t$ test.

2. Overall odds ratio adjusted for current relative body weight

The Mantel-Haenszel odds ratios ${ }^{10)}$ adjusted for the current relative body weight in the rapid weight-gain group were calculated with the moderate weight-gain group used as control. The significance of the odds ratio was tested using its $95 \%$ confidence interval ${ }^{10}$.

3. Comparison of the weight history in the significant odds ratio

Comparisons between abnormal and normal findings of the significant medical test items were made based on current age, age at the start and the completion of the weight-gain, duration of the weight gain, amount of the weight gain and current relative body weight. Statistical comparison was conducted by Student's $t$ test.

4. Multivariate analysis for determining the factors related to the occurrence of abnormal findings

The factors which were considered as influencing the occurrence of abnormal findings were evaluated using stepwise logistic regression ${ }^{11}$. The odds ratio, together with its $95 \%$ confidence interval, was calculated on the basis of the regression coefficient and its standard error in the logistic equation ${ }^{10}$.

\section{RESULTS}

1. Comparison of the prevalence between the different temporal courses of weight gain

Table 1 shows the comparison of age and weight history between the different temporal courses of weight gain. Subject age at the completion of weight gain was higher in the moderate weight-gain group than in the rapid weight-gain group. The duration of the weight gain in the moderate weight-gain group was significantly longer than in the rapid weight-gain group, while the current relative body weight and the amount of weight gain in the rapid weight-gain group were significantly higher than those of the moderate weight-gain group.

Table 1 Comparison of age and weight history by rate of weight gain.

\begin{tabular}{|c|c|c|}
\hline & \multicolumn{2}{|c|}{ Rate of weight gain } \\
\hline & Rapid group & Moderate group \\
\hline & $(\mathrm{N}=167)$ & $(\mathrm{N}=212)$ \\
\hline Age (y.o.) & $45.8 \pm 5.5$ & $46.4 \pm 4.8$ \\
\hline Age at start of weight gain (y.o.) & $27.8 \pm 4.7$ & $27.6 \pm 3.8$ \\
\hline Age at completion of weight gain (y.o.) & $34.9 \pm 5.1$ & $41.7 \pm 5.4 * *$ \\
\hline Duration (years) & $7.1 \pm 3.7$ & $14.1 \pm 4.5 * *$ \\
\hline Amount of gain $(\mathrm{kg})$ & $13.9 \pm 4.5$ & $11.6 \pm 4.0 * *$ \\
\hline Relative body weight $(\%)^{1}$ & $11.8 \pm 10.4$ & $8.7 \pm 9.9 * *$ \\
\hline
\end{tabular}

$1:$ Relative body weight was calculated based on the modified Broca method. $* *: p<0.01$

2. The prevalence of abnormal findings in the different temporal courses of weight gain

Table 2 shows the prevalence of abnormal findings of the medical test items in the different temporal courses of weight gain. In the group whose current relative body weight was equal to and over $+10 \%$, 92 subjects (48.9\%) belonged to the rapid weight-gain group and 96 subjects $(51.1 \%)$ belonged to the 
Table 2 Prevalence of abnormal findings by relative body weight and rate of weight gain.

\begin{tabular}{|c|c|c|c|c|}
\hline & \multicolumn{4}{|c|}{ Relative body weight } \\
\hline & \multicolumn{2}{|c|}{$>=+10 \%$} & \multicolumn{2}{|c|}{$<+10 \%$} \\
\hline & Rapid & Moderate & Rapid & Moderate \\
\hline & $(\mathrm{N}=92)$ & $(\mathrm{N}=96)$ & $(\mathrm{N}=75)$ & $(\mathrm{N}=116)$ \\
\hline $\mathrm{SBP}^{1}$ & $10 / 84(11.9)$ & $10 / 89(11.2)$ & $7 / 69(10.1)$ & $8 / 98(8.2)$ \\
\hline $\mathrm{DBP}^{2}$ & $17 / 84 \quad(20.2)$ & $18 / 89(20.2)$ & $6 / 69(8.7)$ & $10 / 98(10.2)$ \\
\hline $\mathrm{TC}^{3}$ & $18 / 90(20.0)$ & $27 / 95 \quad(28.4)$ & $8 / 71 \quad(11.3)$ & $20 / 115(17.4)$ \\
\hline $\mathrm{TG}^{4}$ & $26 / 89 \quad(29.2)$ & $32 / 95 \quad(33.7)$ & $7 / 71 \quad(9.9)$ & $16 / 114(14.0)$ \\
\hline $\mathrm{FBG}^{5}$ & 17/88 (19.3) & $7 / 91(7.7) *$ & $8 / 68(11.8)$ & $5 / 111(4.5) *$ \\
\hline $\mathrm{UA}^{6}$ & $22 / 90 \quad(22.2)$ & 25/95 (26.3) & $8 / 70(11.4)$ & $18 / 115(15.7)$ \\
\hline
\end{tabular}

$*: p<0.05$ Numbers in parentheses indicate percentages. $1:$ Systolic blood pressure $>=140 \mathrm{mmHg}$ 2: Diastolic blood pressure $>=90 \mathrm{mmHg} \quad 3:$ Total Cholesterol $>=230 \mathrm{mg} / \mathrm{d} l \quad 4:$ Triglyceride $>=200 \mathrm{mg} / \mathrm{d} l$ 5: Fasting blood glucose $>=110 \mathrm{mg} / \mathrm{d} l \quad 6:$ Uric acid $>=7.0 \mathrm{mg} / \mathrm{d} l$

moderate weight-gain group. In contrast, in the group whose current relative body weight was less than $+10 \%$, 75 subjects (39.3\%) belonged to the rapid weight-gain group and 116 subjects (60.7\%) belonged to the moderate weight-gain group.

Regardless of the current relative body weight, the prevalence of an abnormal fasting blood glucose level was significantly higher in the rapid weight-gain group than in the moderate weight-gain group. No significant differences were observed in the other medical test items.

3 . Odds ratios adjusted for the current relative body weight

Table 3 shows the Mantel-Haenszel overall odds ratios adjusted for the current relative body weight for each medical test item. The Mantel-Haenszel odds ratio for the abnormal fasting blood glucose levels was 2.86 (95\% C.I. : $1.35-6.06$ ). There was a significantly high odds ratio for the abnormal fasting blood glucose levels in the rapid weight-gain group. No significant odds ratios were noted for the other medical test items.

Table 3 Mantel-Haenszel overall odds ratio adjusted for relative body weight.

\begin{tabular}{lc}
\hline & Odds ratio $(95 \%$ C.I. $)$ \\
\hline SBP & $1.15(0.31-4.20)$ \\
DBP & $0.94(0.03-31.64)$ \\
TC & $0.62(0.35-1.11)$ \\
TG & $0.76(0.42-1.39)$ \\
FBG & $2.86(1.35-6.06)$ \\
UA & $0.82(0.43-1.58)$ \\
\hline
\end{tabular}

Abbreviations are defined in Table 2.

4. Comparison of the weight history for the abnormal fasting blood glucose levels

Table 4 shows the comparison of age and weight history. Age, amount of weight gain and current relative body weight were significantly higher in subjects having abnormal fasting blood glucose levels than in those having normal levels.

5. Multivariate evaluation of the factors related to the occurrence of abnormal fasting blood glucose levels

Table 4 suggests that age, amount of weight gain and current relative body weight are associated with the occurrence of abnormal fasting blood glucose levels. 
Table 4 Comparison of age and weight history based on determination of fasting blood glucose.

\begin{tabular}{|c|c|c|}
\hline & \multicolumn{2}{|c|}{ Fasting blood glucose } \\
\hline & $<110 \mathrm{mg} / \mathrm{d} l$ & $>=110 \mathrm{mg} / \mathrm{d} l$ \\
\hline & $(\mathrm{N}=321)$ & $(\mathrm{N}=37)$ \\
\hline Age (у.о.) & $45.9 \pm 5.0$ & $48.3 \pm 4.8 * *$ \\
\hline Age at start of weight gain (y.o.) & $27.6 \pm 4.1$ & $27.9 \pm 4.5$ \\
\hline Age at completion of weight gain (y.o.) & $38.8 \pm 6.2$ & $37.5 \pm 6.2$ \\
\hline Duration (years) & $11.3 \pm 5.4$ & $9.5 \pm 4.7$ \\
\hline Amount of gain $(\mathrm{kg})$ & $12.4 \pm 4.4$ & $14.1 \pm 4.3 * *$ \\
\hline Relative body weight $(\%)^{1}$ & $9.8 \pm 9.9$ & $13.9 \pm 11.3 *$ \\
\hline
\end{tabular}

$*: p<0.05, * *: p<0.01 \quad 1:$ Refer to Table 1.

For the purpose of determining the factors related to the occurrence of the abnormal fasting blood glucose levels, stepwise logistic regrssion was performed by selecting these factors and the rate of weight gain as independent variables. Age and rate of weight gain were adopted to the logistic regression for determining the abnormal fasting blood glucose levels. The odds ratio of the abnormal fasting blood glucose levels calculated from the regression coefficient and its standard error was 1.78 (95\% C.I. : 1.24 $-2.57)$.

\section{Discussions}

Long-term weight gain has been a useful indicator of health risk associated with cardiovascular disease $^{5,6,12)}$. Matsuda ${ }^{7)}$ reported that a weight gain of more than 7 kilograms since adolescence may constitute a critical level of health risk on the basis of analyses of occupational medical data. However, health risks related to the temporal course of weight gain remain to be elucidated.

It may be of significance to determine the persons at high risk from similar weight-gain groups using the rate of weight gain as an indicator if the temporal course of the weight gain could be taken as an influencing factor in health risk. Thus, this study has aimed to epidemiologically evaluate the significance of the temporal course of weight gain since adolescence.

The overall odds ratio, adjusted for the current relative body weight with respect to abnormal fasting blood glucose levels, was significantly high in the rapid weight-gain group. In addition, even after being adjusted for other factors related to the occurrence of abnormal fasting blood glucose levels by multivariate analysis, the rapid weight-gain group had a significantly high odds ratio. Borkan et al. ${ }^{13)}$ reported that weight gain since adolescence influenced the incidence of abnormal fasting blood glucose levels. This study clarified that rapid weight gain was a risk indicator for abnormal fasting blood glucose levels even in subjects whose amount of weight gain was similar.

The temporal course of weight gain has been considered to be related to the induction of glucose intolerance. It is well known that obesity stimulates the secretion of insulin from the pancreas ${ }^{14 \sim 16)}$. Rapid weight gain can thus be expected to exhaust the capability of insulin secretion in the Langerhans' islets, and may be the reason why the pancreatic exhaustion induced by rapid weight gain causes the glucose intolerance that appears in later life.

In this study, the referral value of glucose intolerance was a fasting blood glucose level of $110 \mathrm{mg} /$ $\mathrm{d} l$. This value of fasting blood glucose differs from the diagnostic criteria for clinical diabetes mellitus ${ }^{17)}$. Therefore, the results of this study did not clarify whether rapid weight gain influenced the incidence of clinical diabetes mellitus. However, glucose intolerance is recognized as a risk indicator for ischemic heart diseases ${ }^{18)}$. Thus, rapid weight gain may be a useful indicator for detecting persons at high risk from these diseases.

The following two limitations were considered in this study. First, a family history of diabetes mellitus was not surveyed in this study. A hereditary predisposition to diabetes mellitus is known to influence the occurrence of glucose intolerance ${ }^{17)}$. It was not elucidated whether rapid weight gain 
constituted an accompanying phenomenon in terms of hereditary predisposition toward glucose intolerance or whether rapid weight gain independently caused glucose intolerance. A family history of glucose intolerance might also have to be taken into account for evaluating abnormal fasting blood glucose levels. Second, the health status of the subjects at the time they were hired was not confirmed, although normally workers in Japanese companies are considered to be selected on the basis of the health checkups performed on hiring ${ }^{19}$. It cannot be assumed that persons having glucose intolerance tended to be incorporated into the study samples. Further research will be needed to eliminate the limitations of this study.

However, rapid weight gain may be a risk indicator for glucose intolerance in later life among persons experiencing similar weight gain.

Accordingly, the temporal course of weight gain should be used when assessing health effects influenced by obesity.

A part of this study was reported at the fifty-ninth annual meeting of the Japanese Society for Hygiene on May 3rd, 1989 in Akita. This study was supported by a Grant-in-Aid from the Life Insurance Association of Japan.

\section{SUMMARY}

Health risks induced by the temporal course of weight gain were studied. Of 1,627 male company employees, 437 subjects were selected as follows. The criteria for eligibility were: 1) A subject must have undergone more than 20 health checkups. 2) The subject's weight gain since adolescence must have exceeded 7 kilograms. Four hundred and thirty-seven subjects were selected using these criteria. The average subject's age was $46.2 \pm 5.1$ (Mean \pm S.D.) years. Subjects were classified into 3 groups according to the rate of weight gain. As a result, 167 were classified as the rapid weight-gain group (defined as a weight gain of more than 5 kilograms per 5 years), 212 were designated as the moderate weight-gain group (less than 5 kilograms per 5 years) and 58 were assigned to a miscellaneous group (temporal weight loss during the observation period). This miscellaneous group was excluded from further analysis. Comparison between the rapid and moderate weight-gain groups indicated that the prevalence of abnormal fasting blood glucose levels was significantly higher in the rapid weight-gain group than in the moderate group $(p<0.01)$. The Mantel-Haenszel overall odds ratio adjusted for the current relative body weight for the abnormal fasting blood glucose level was 2.86 (95\% C.I. : 1.35-6.06). To determine the factors related to the occurrence of abnormal fasting blood glucose levels, stepwise logistic regression was performed by selecting the rate of weight gain, age, weight gain amount and current relative body weight as independent variables. Age and rate of weight gain were shown to be significant variables in abnormal fasting blood glucose levels. Accordingly, the rate of weight gain should be used when assessing the health risk induced by obesity.

\section{REFERENCES}

1) Rimm, A.A. and White, P.L.: Obesity: Its risks and hazards, On obesity in America, NIH Pub., 103-124 (1979).

2) National Institutes of Health Consensus Development Conference Statement: Health implications of obesity, Ann. Intern. Med., 103, 1073-1077 (1985).

3) Keys, A., Fidanza, F., Karvonen, M.J., Kimura, N. and Taylor, H.L. : Indices of relative weight and obesity, J. Chron. Dis., 25, 329-343 (1972).

4) Revicki, D.A. and Israel, R.G. : Relationship between body mass indices and measures of body adiposity, Am. J. Public Health, 76, 992-994 (1986).

5) Hubert, H.B., Feinleib, M., McNamara, P.M. and Castelli, P.: Obesity as an independent risk factor for cardiovascular disease: A 26-year follow-up participants in the Framingham heart study, Circulation, 67, 968 -977 (1983).

6) Ashley, F.W. and Kannel, W.B.: Relation of weight change to changes in atherogenic traits: The Framingham Study, J. Chron. Dis., 27, 103-114 (1974).

7) Matsuda, H.: Risk assessment of long-term weight history, J.J.P.H. (in press). (in Japanese) 
8) Muto, T.: Pattern and tracking of blood pressure over a 30-year observation period, and predictive value of blood pressure for hypertension, J. Keio Med. Soc., 67, 121-135 (1990). (in Japanese)

9) Wyngaarden, J.B. : The use and interpretation of laboratory-derived data, In "Cecil Textbook of Medicine, Vol. 1", (Editors: Wyngaarden, J.B. and Smith, L.H.), pp. 79-82, Saunders, Philadelphia (1989).

10) Kahn, H.A.: An introduction to epidemiologic methods, Oxford University Press, New York (1983).

11) Engelman, L.: Stepwise logistic regression, In "BMDP statistical software", pp. 330-342, University of California Press, Berkeley (1983).

12) Kannel, W.B., LeBauer, E.J., Dawber, T.R. and McNamara, P.M. : Relation of body weight to development of coronary heart disease, The Framingham Study, Circulation 35, 734-744 (1967).

13) Borkan, G.A., Sparrow, D., Wisniewski, C. and Vokonas, P.S. : Body weight and coronary disease risk: patterns of risk factor change associated with long-term weight change, The Normative Aging Study, Am. J. Epidemiol., 124, 410-419 (1986).

14) O'Sullivan, J.B. and Mahan, C.M. : Blood sugar levels, glycosuria, and body weight related to development of diabetes mellitus, The Oxford epidemiologic study 17 years later, JAMA, 194, 587-592 (1965).

15) Kissebah, A.V., Vydelingum, N., Murray, R., Evans, D.J., Hartz, A.J., Kalkhoff, R.K. and Adams, P.W. : Relation of body fat distribution of metabolic complications of obesity, J. Clin. Endocrinol. Metab., 54, 254260 (1982).

16) Dietz, W.H.: Obesity, J. Am. Coll. Nutr., 8, 13-21 (1989).

17) Olefsky, J.M. : Diabetes Mellitus, In “Cecil Textbook of Medicine, Vol. 2”, pp. 1360-1381, Saunders, Philadelphia (1989).

18) Eschwege, E., Ducimetiere, P., Papoz, L., Claude, J.R. and Richard, J.L.: Blood glucose and coronary heart disease, Lancet, 8192, 472-473 (1980).

19) Higashi, T., Baba, Y., Fujino, A., Sakurai, H. and Omae, K.: Healthy worker effect on Japanese Industry workers: A commentary from the viewpoint of industrial health management, J. UOEH, 11, 305-311 (1989).

\section{体重増加速度による健康危険度評価}

\section{慶應義塾大学医学部衛生学公衆衛生学教室

吉 田勝 美・松 田 弘史・武 藤 孝 司
桜 井 治 彦・近 藤 東 郎

長期の体重変動が, 肥満の健康影響を評価する上で, 関心を呼んでいる。体重の増加量が及ぼす健康影響は知られる ものの, 体重増加の時間的経緯による健康影響については, ほとんど知られていない。本研究の目的は, 体重増加の時 間的経緯として, 増加速度がもたらす健康影響を評価することである。某企業の 1,627 名男子従業員の中から, 次の基準 により，解析対象を選択した。選択基準は，以下のごとくである。1）対象者は，少なくとも20回以上の健康診断を受 診している。2）対象者は，青年期より $7 \mathrm{~kg}$ 以上の体重増加を認める。上記の基準により，437名が選択された。対象者 の年齢は, $46.2 \pm 5.1$ 歳 $(\mathrm{M} \pm$ S.D.) であった。体重の増加速度により, 対象者を以下の 3 群に分けた。急速体重増加群 は, 5 年間に $5 \mathrm{~kg}$ 以上の増加を認めた者であり, 167 名が分類された。緩徐体重増加群は, 5 年間に $5 \mathrm{~kg}$ 未満の体重増 加を認めた者であり, 212名が分類された。観察期間中に, 一時的な体重減少を認めた残りの 58 名は, その他の群として, 以下の解析から除外した。現時点の比体重を補正した Mantel-Haenszel odds 比は, 空腹時血糖の有所見 $(110 \mathrm{mg} / \mathrm{d} l$ 以 上）に関して，急速体重増加群で有意に高かった。また，体重増加速度以外の要因を含めたロジスティック解析の結果 では, 空腹時血糖の有所見に関するロジスティック式に, 年齢とともに体重増加速度が取り込まれ, 体重増加速度の odds 比は, 2.86 (95\% C.I. : 1.35-6.06) であった。血圧, 総コレステロール, 中性脂肪, 尿酸の有所見の発現に関して, 体 重増加の有意な関係は認めなかった。以上より, 青年期から $7 \mathrm{~kg}$ 以上の体重増加を認めた者において, 体重増加速度が 糖代謝異常の発現に関連していることが示され, 体重増加速度が有する健康危険指標の意義が確認された。

Key words : Weight gain, Glucose intolerance, Weight history, Risk assessment 体重増加, 糖代謝異常, 長期体重変動, 危険評価 